\title{
EFFECT OF CARBON SOURCES ON XANTHAN PRODUCTION BY XANTHOMONAS SPP. ISOLATED FROM PEPPER LEAVES
}

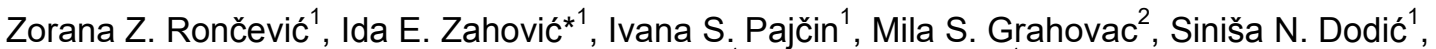 \\ Jovana A. Grahovac ${ }^{1}$, Jelena M. Dodić ${ }^{1}$ \\ ${ }^{1}$ University of Novi Sad, Faculty of Technology Novi Sad, 21000 Novi Sad, Bulevar cara Lazara 1, \\ Serbia \\ ${ }^{2}$ University of Novi Sad, Faculty of Agriculture, 21000 Novi Sad, Trg Dositeja Obradovića 8, \\ Serbia
}

\author{
*Corresponding author: \\ Phone: +381655661243 \\ Fax: +38121450413 \\ E-mail address: ida.zahovic@tf.uns.ac.rs
}

\begin{abstract}
Xanthan is the most important microbial exopolysaccharide used in different branches of food and non-food industry. Due to high consumption of glucose and sucrose, usually utilized carbon sources in many bioprocesses, the most prominent research in xanthan production is related to the isolation of new xanthan producing strains capable to metabolize other carbon sources and to produce xanthan with characteristics appropriate for usage in food industry. The aim of this study was to examine the effect of variation of carbon sources in cultivation media on xanthan production by reference strain Xanthomonas campestris ATCC 13951 and five Xanthomonas strains isolated from infected pepper leaves. Bioprocess efficacy was estimated based on the quantity and quality of biosynthesized xanthan. The obtained results show that both, the selection of the carbon source and selection of producing strain have a statistically significant effect on bioprocess efficacy whereby the influence of carbon sources on the analyzed parameters is more pronounced. It was confirmed that Xanthomonas strains responsible for the production of a large amount of xanthan are not suitable for biosynthesis of good-quality biopolymer. Taking into account all results it can be concluded that the greatest potential in biotechnological xanthan production has strain PFNS PL4 and glucose or starch containing media which is the basis for further research.
\end{abstract}

Keywords: biotechnological production, xanthan, Xanthomonas campestris, cultivation medium composition, carbon source

\section{INTRODUCTION}

Xanthan is a water soluble microbial exopolysaccharide, composed of glucose, mannose, and glucuronic acid units, that is produced using bacteria of the genus Xanthomonas (Petri, 2015). Due to its unique rheological properties and insensitivity to variation in salt concentration, $\mathrm{pH}$ value and temperature, xanthan is commercially the most important biopolymer widely used in food, pharmaceutical, petrochemical, cosmetic, textile and other industries as well as in agriculture (Rosalam and En- gland, 2006; de Mônaco Lopes et al., 2015; Petri, 2015).

Except of excellent rheological behavior, biocompatibility, non-toxicity and biodegradability of xanthan are the main reasons why novel applications of xanthan appear continuously (Sharma et al., 2006). The most advanced application of xanthan is in food industry as a suspending and thickening agent (Infee Sherley and Priyadharshini, 2015). In addition, xanthan controls the rheology and improves texture, 
volume, viscosity, flavor release, and appearance of the final food product ( $\mathrm{Pa}$ laniraj and Jayaraman, 2011). Xanthan is widely used in salad dressings as it provides easy pourability and keeps the dressing on the top of the salad (Abedinzadeh et al., 2016). In bakery industry, xanthan is used primarily to increase water binding during baking and to improve texture of the bread and pastry, including gluten-free bakery products (Preichardt et al., 2011). The use of xanthan in beverages helps in maintaining the suspension, resulting in good product appearance and texture (Saha and Bhattacharya, 2010). Besides all mentioned, xanthan is an excellent thickening agent for butter creams, ice creams, chocolate and other edible coatings (Palaniraj and Jayaraman, 2011; Šuput et al., 2015).

Xanthan is produced industrially by aerobic submerged batch cultivation of reference strain Xanthomonas campestris ATCC 13951 on the appropriate medium under optimal conditions (de Mônaco Lopes et al., 2015). Glucose, sucrose, starch, molasses and corn syrup are the most commonly used carbon sources in the production medium but the industrial production of xanthan is mainly based on the usage of glucose or sucrose containing media (Becker et al., 1998; de Mônaco Lopes et al., 2015; Petri, 2015). However, the rise in prices and the growing demand for mentioned components indicate the need for usage of another sugar or alternative substrates with lower price. The lack of this idea is difficulty of the reference strain to successfully metabolize other carbon sources as glucose or sucrose (Roseiro et al., 1992).

Considering all mentioned facts it can be concluded that there is a need for selection of new xanthan producing strains and alternative fermentable substrates. Accordingly, researches are focused on optimization of these segments of xanthan production process in order to increase the yield, but also the quality of the synthesized biopolymer (Niknezhad et al., 2016). The results of published studies indicate that Xanthomonas strains isolated from brassicas, pepper and cotton leaves were successfully used for xanthan biosynthesis (Selva Mohan and Babitha, 2010; Rončević et al., 2018). In addition, since it is possible to isolate the strains with ability to metabolize different carbon sources in order to produce xanthan, there is also a possibility of using waste streams with that carbon sources as raw materials in the biotechnological xanthan production (Bajić et al., 2014; Bajić et al., 2015). This indicates that apart from decrease of the production costs, reduction of environmental pollution and improvement of already existing wastewater treatment systems can be also achieved in this way (Green et al., 1994). Moreover, new studies are being focused on isolation of new strain which can produce xanthan with better structure and rheological characteristics.

The aim of this study was to evaluate the effect of various carbon sources in cultivation media on xanthan production by the reference strain Xanthomonas campestris ATCC 13951 and different Xanthomonas strains isolated from pepper leaves. Process efficacy was estimated based on the quantity and quality of biosynthesized xanthan.

\section{MATERIALS AND METHODS}

\section{Producing microorganism}

The reference strain Xanthomonas campestris ATCC 13951 and five strains isolated from pepper leaves (PFNS PL1, PFNS PL2, PFNS PL3, PFNS PL4, PFNS $P L 5)$, identified as bacteria of the genus Xanthomonas (Grahovac et al., 2016), were used as the producing microorganism in these experiments. The cultures were stored at $4{ }^{\circ} \mathrm{C}$ on agar slant (YMA®, HiMedia, India) and subcultured at four-week intervals.

\section{Cultivation media}

The commercial medium (YMB®, HiMedia, India) was used for inoculum preparation, while xanthan production was performed on semi-synthetic media with various carbon sources. Glucose, lactose and starch (potato, soluble) were investigated as sources of this nutrient and used in a quantity of $20.0 \mathrm{~g} / \mathrm{L}$. The cultivation media also contained yeast extract $(3.0 \mathrm{~g} / \mathrm{L})$, 
$\left(\mathrm{NH}_{4}\right)_{2} \mathrm{SO}_{4}(1.5 \mathrm{~g} / \mathrm{L}), \mathrm{K}_{2} \mathrm{HPO}_{4}(3.0 \mathrm{~g} / \mathrm{L})$ and $\mathrm{MgSO}_{4} \cdot 7 \mathrm{H}_{2} \mathrm{O}(0.3 \mathrm{~g} / \mathrm{L})$. The $\mathrm{pH}$ value of all used media was adjusted to $7.0 \pm 0.2$ and then sterilized by autoclaving at $121^{\circ} \mathrm{C}$ and 2.1 bar for 20 min.

\section{Xanthan production}

The xanthan production was carried out in $300 \mathrm{~mL}$ Erlenmeyer flasks with $100 \mathrm{~mL}$ of the cultivation medium with the appropriate composition. Inoculation was performed by adding $10 \%$ (v/v) of inoculum prepared in aerobic conditions at $25{ }^{\circ} \mathrm{C}$ and $150 \mathrm{rpm}$ (laboratory shaker KS 4000i control, Ika ${ }^{\circledR}$ Werke, Germany) for $48 \mathrm{~h}$. The biosynthesis was carried out in batch mode under aerobic conditions at $30{ }^{\circ} \mathrm{C}$ and $150 \mathrm{rpm}$ for $120 \mathrm{~h}$.

\section{Determination of cultivation medium rheological properties}

The rheological properties of cultivation medium samples taken after $120 \mathrm{~h}$ of cultivation were determined using rotational viscometer (REOTEST 2 VEB MLV Prufgerate-Verk, Mendingen, SitzFreitel) with double gap coaxial cylinder sensor system, spindle $\mathrm{N}$. Based on deflection of measuring instrument ( $\alpha$, Skt), shear stress ( $\tau, P a)$ was calculated under defined values of shear rates (D, 1/s) using the Eq. (1):

$$
\mathrm{T}=0.1 \cdot \mathrm{z} \cdot \alpha
$$

where $z$ is the constant with the value 3.08 $\mathrm{dyn} / \mathrm{cm}^{2}$. Skt. The pseudoplastic behavior of the cultivation medium was confirmed by fitting the experimental data to the Ostwald-de-Waele model using the power regression. The values of the consistency factor $\left(\mathrm{K}, \mathrm{Pa} \cdot \mathrm{s}^{\mathrm{n}}\right)$, flow behavior index $(\mathrm{n})$ and determination coefficient $\left(R^{2}\right)$ were determined by Excel software 2010 and used for calculation of medium apparent viscosity $\left(\eta_{a}, \mathrm{mPa} \cdot \mathrm{s}\right)$ from Eq. (2):

$\eta_{a}=K \cdot D^{n-1}$

where $D$ is shear rate with the value of 100 $1 / \mathrm{s}$.

\section{Determination of xanthan quantity}

At the end of biosynthesis, the xanthan was separated from the supernatant of cultivation medium by precipitation with cold $96 \%(\mathrm{v} / \mathrm{v})$ ethanol in the presence of the potassium-chloride as electrolyte. Supernatant was obtained using an ultracentrifuge (Hettich Rotina 380 R, Germany) at $10000 \mathrm{rpm}$ for $10 \mathrm{~min}$. The preparation of starch-containing medium samples included hydrolysis prior to centrifugation, using the commercial enzymes (Alkozym Plus and Alkozym HT, Alkozym $\mathrm{GmbH}$, Germany) at conditions defined by the producer. Ethanol was gradually added to the supernatant at constant stirring until the alcohol content in mixture was $60 \%(\mathrm{v} / \mathrm{v})$. Prior to this, a saturated solution of potassium-chloride was added into the cell-free supernatant in a quantity to obtain a final content of $1 \%(\mathrm{v} / \mathrm{v})$. The obtained mixture was kept at $4{ }^{\circ} \mathrm{C}$ for $24 \mathrm{~h}$ in order to dehydrate the precipitated xanthan, and then centrifuged at $4000 \mathrm{rpm}$ for 15 min (Tehtnica LC-321, Slovenia). The precipitated biopolymer was dried to constant weight at $60{ }^{\circ} \mathrm{C}$ in order to determine the xanthan quantity. Ethanol used for xanthan precipitation was recycled by distillation.

\section{Determination of xanthan solution ap- parent viscosity}

Apparent viscosity of $0.5 \%(\mathrm{w} / \mathrm{v})$ aqueous xanthan solution was calculated based on results of measurement on rotational viscometer (REOTEST 2 VEB MLV Prufgerate-Verk, Mendingen, SitzFreitel) with double gap coaxial cylinder sensor system, spindle $\mathrm{N}$, as previously described.

\section{Statistical analysis}

All experiments were carried out in triplicate and the results were averaged. The experimental data were processed by twoway analysis of variance (two-way ANOVA). Significant differences between the means were determined by Duncan's multiple range test at the significance level of $\alpha=0.05$ using Statistica 13.2 software (Dell Inc., USA).

\section{RESULTS AND DISCUSSION}

In accordance with the defined aim of this research, xanthan biosynthesis was performed by several Xanthomonas strains on cultivation media with different carbon sources, i.e. glucose, lactose and 
starch which represent substrates for xanthan production (Leela and Sharma, 2000). Since the xanthan solutions and xanthan cultivation broths are highly viscous even at low biopolymer con-centrations and show pseudoplastic behavior (García-Ochoa et al., 2000), the metabolic activities of examined bacterial strains and the possibility of xanthan production under the applied experimental conditions were evaluated comparing the rheological properties of cultivation media before inoculation and after biosynthesis. The rheological parameters were determined from the relationship between shear rate and shear stress, and obtained values are presented in Table 1 as well as in Table 2 along with other indicators of xanthan biosynthesis.
Flow behavior index (n) shows a level of deviation from Newtonian flow behavior. For a Newtonian fluid, flow behavior index is equal to 1 , greater than 1 for a dilatant and less than 1 for a pseudoplastic fluid (Björn et al., 2012). In this research, values of flow behavior index for cultivation media obtained after biosynthesis were in the range of 0.3900-0.5377 (Table 2 ), which is similar to the results from available literature (Rončević et al., 2017). Considering that these data are different in relation to the values of the same parameter determined before inoculation (0.4079-0.5549; see Table 1), it can be assumed that metabolic activity of all used producing microorganisms occurred under the applied experimental conditions on all investigated media.

Table 1.

Rheological properties of cultivation media with various carbon sources before inoculation

\begin{tabular}{ccccc}
\hline Carbon source & $\mathbf{n}$ & $\mathbf{K}\left(\mathbf{P a} \cdot \mathbf{s}^{\mathbf{n}}\right)$ & $\mathbf{R}^{\mathbf{2}}$ & $\mathbf{\eta}_{\mathbf{a}}(\mathbf{m P a} \cdot \mathbf{s})$ \\
\hline Glucose & 0.4678 & 0.0676 & 0.956 & 5.83 \\
Lactose & 0.4079 & 0.0871 & 0.963 & 5.70 \\
Starch & 0.5549 & 0.1102 & 0.980 & 14.19 \\
\hline
\end{tabular}

$n$ - flow behavior index; $K$ - consistency factor; $R^{2}$ - determination coefficient;

$\eta_{a}$ - apparent viscosity

Table 2.

Indicators of xanthan biosynthesis by different Xanthomonas strains on media with various carbon sources after $120 \mathrm{~h}$ of cultivation under applied conditions $\left(30^{\circ} \mathrm{C}, 150 \mathrm{rpm}\right)$

\begin{tabular}{cccccc}
\hline Xanthomonas strain & Carbon source & $\mathbf{n}$ & $\mathbf{K}\left(\mathbf{P a} \cdot \mathbf{s}^{\mathbf{n}}\right)$ & $\mathbf{R}^{\mathbf{2}}$ & $\mathbf{n}_{\mathbf{a}}(\mathbf{m P a} \cdot \mathbf{s})$ \\
\hline \multirow{3}{*}{ ATCC 13951 } & Glucose & 0.4656 & 0.3250 & 0.992 & 27.74 \\
& Lactose & 0.4912 & 0.0899 & 0.995 & 8.63 \\
& Starch & 0.4699 & 0.1449 & 0.908 & 12.61 \\
\hline \multirow{2}{*}{ PFNS PL1 } & Glucose & 0.5377 & 0.0952 & 0.993 & 11.32 \\
& Lactose & 0.4869 & 0.0872 & 0.923 & 8.21 \\
& Starch & 0.4820 & 0.0913 & 0.903 & 8.40 \\
\hline \multirow{2}{*}{ PFNS PL2 } & Glucose & 0.5205 & 0.1557 & 0.994 & 17.11 \\
& Lactose & 0.4968 & 0.0730 & 0.972 & 7.19 \\
& Starch & 0.4449 & 0.1243 & 0.947 & 9.64 \\
\hline \multirow{2}{*}{ PFNS PL3 } & Glucose & 0.4978 & 0.2379 & 0.998 & 23.55 \\
& Lactose & 0.5100 & 0.0998 & 0.950 & 10.45 \\
& Starch & 0.5106 & 0.0941 & 0.975 & 9.88 \\
\hline \multirow{2}{*}{ PFNS PL4 } & Glucose & 0.4719 & 0.2944 & 0.999 & 25.87 \\
& Lactose & 0.5252 & 0.0794 & 0.998 & 8.92 \\
& Starch & 0.3900 & 0.0995 & 0.914 & 6.00 \\
\hline \multirow{2}{*}{ PFNS PL5 } & Glucose & 0.5164 & 0.1078 & 0.996 & 11.63 \\
& Lactose & 0.4513 & 0.0865 & 0.965 & 6.91 \\
& Starch & 0.4883 & 0.0756 & 0.971 & 7.16 \\
\hline
\end{tabular}

$n$ - flow behavior index; $K$ - consistency factor; $R^{2}$ - determination coefficient; $\eta_{a}$ - apparent viscosity 
In addition, high values of the coefficient of determination $\left(R^{2}>0.908\right)$ indicate a very good corresponding of the measured values with the Ostwald-de-Waele model, which further confirms pseudoplastic behavior of all tested samples.

The viscosity of xanthan solution depends on the concentration of the biopolymer, but also on its structure (García-Ochoa et al., 2000). Taking into account that the consistency factor is proportional to the viscosity, the different values of this parameter shown in Table 2 indicate the difference in the quantity and quality of xanthan produced under the applied experimental conditions using different Xanthomonas strains on media with various carbon sources. This is in accordance with the values of apparent viscosity shown in the same table. Also, it can be noticed that media based on glucose and lactose were more viscous at the end of cultivation than before inoculation for all investigated strains (Table 1), which was not the case with the starch containing medium. This is probably due to the fact that both, the reference strain Xanthomonas campestris ATCC 13951 and Xanthomonas strains isolated from the environment have the ability to synthesize amylolytic enzymes responsible for hydrolysis of starch (de Crecy-Lagard, et al., 1990).

The values of rheological parameters and the highest values of apparent viscosity given in Table 2 indicate that the greatest bioprocess success was most likely achieved by cultivation of all applied Xanthomonas strains on glucose containing medium. It can also be noticed that there was no significant difference between the lactose and starch containing medium. However, in order to select the most productive strain and the most suitable carbon source, it is necessary to carry out a more detailed analysis of the effect of mentioned parameters on the quantity and quality of xanthan. To accomplish this, it is necessary to perform statistical analysis of experimentally obtained values for indicators of process efficacy and to make appropriate data interpretation.

\section{Effect of producing strain and carbon source on xanthan quantity}

In order to examine the effect of different Xanthomonas strains and carbon sources on xanthan concentration in media at the end of biosynthesis, statistical analysis of experimental data was carried out. The results of Two-Way ANOVA analysis are given in Table 3.

The results presented in Table 3 show that the $p$-values for the analyzed parameters and their interaction are much lower than 0.05 , which indicate that the applied Xanthomonas strains and carbon sources as well as their combination have a statistically significant effect on xanthan concentration in cultivation media as evidenced during other investigations (Rottava et al., 2009; Gumus et al., 2010; Kumara et al., 2012). However, if attention is paid to the mean square values presented in the same table, it can be concluded that the carbon source had a much greater effect on this group of results, while the effect of Xanthomonas strain is considerably lower indicating that the composition of cultivation medium is of critical importance for this bioprocess efficacy. The results of the statistical analysis are also presented graphically in Figures 1 ab. In order to select the combination of the Xanthomonas strain and carbon source for which the highest concentration of xanthan in cultivation media was achieved, the experimental data was analyzed using Duncan's multiple range test (Table 4).

Table 3.

Analysis of variance (Two-Way ANOVA) of the effect of different Xanthomonas strains and carbon sources on xanthan concentration in media after $120 \mathrm{~h}$ of cultivation under applied conditions $\left(30^{\circ} \mathrm{C}\right.$, $150 \mathrm{rpm})$

\begin{tabular}{lrrrrc}
\hline Variability & \multicolumn{1}{c}{ SS } & DF & \multicolumn{1}{c}{ MS } & F-value & $\boldsymbol{p}$-value \\
\hline Xanthomonas strains & 102.670 & 5 & 20.534 & 75.91 & $<0.000001$ \\
Carbon sources & 233.377 & 2 & 116.689 & 431.40 & $<0.000001$ \\
Xanthomonas strains and carbon sources & 239.859 & 10 & 23.986 & 88.68 & $<0.000001$ \\
Error & 9.738 & 36 & 0.270 & & \\
\hline
\end{tabular}

SS - sum of squares; DF - degrees of freedom; MS - mean square 
a)

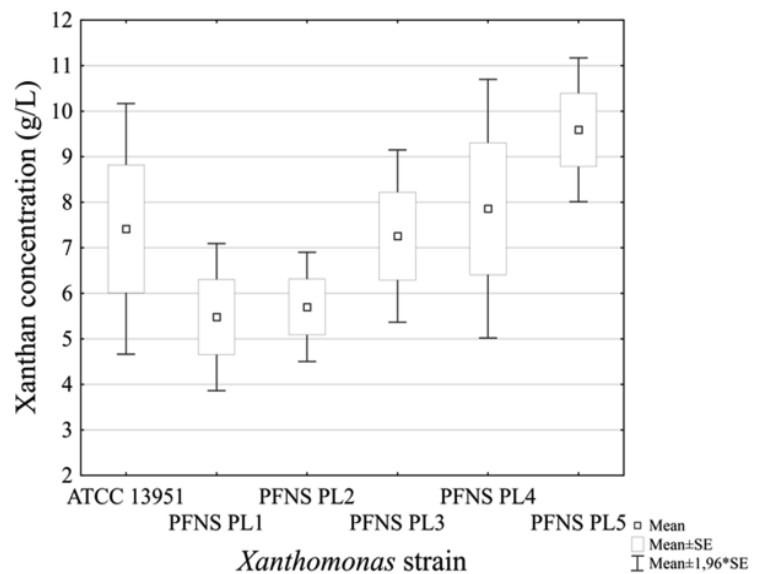

b)

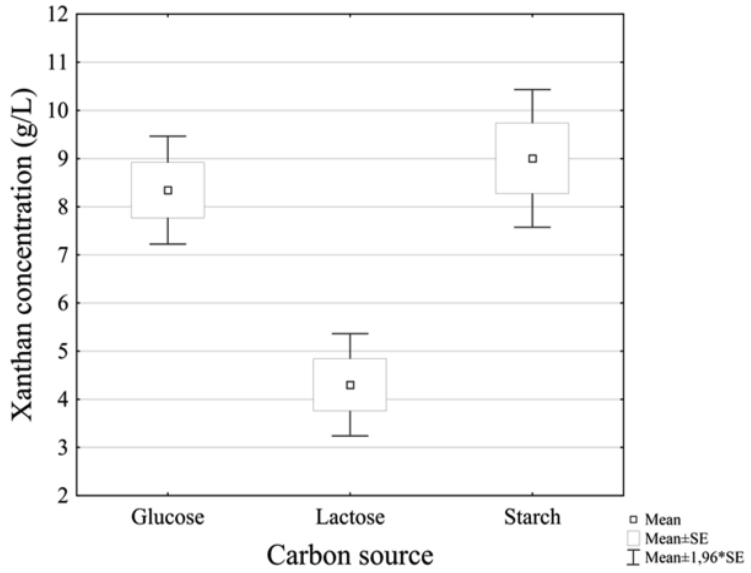

Figure 1. Effect of different Xanthomonas strains (a) and carbon sources (b) on xanthan concentration in media after $120 \mathrm{~h}$ of cultivation under applied conditions $\left(30^{\circ} \mathrm{C}, 150 \mathrm{rpm}\right)$

Figure 1a shows the results of statistical analysis of the effect of the Xanthomonas strains on xanthan concentration in media at the end of biosynthesis. Considering the mean value of biopolymer content for all carbon sources, the strain PFNS PL5 proved to be the best strain for xanthan production in applied experimental conditions. However, individual experiments carried out using this Xanthomonas strain vary widely depending on the carbon source used for medium preparation (Table 4). The highest xanthan concentration $(12.55 \pm 0.78 \mathrm{~g} / \mathrm{L})$ was achieved by cultivation of PFNS PL5 strain on medium based on starch, while biosynthesis conducted with the same strain on the glucose containing medium was less successful as the product content was much lower $(7.19 \pm 0.43 \mathrm{~g} / \mathrm{L})$ but similar to the result from literature data (Roseiro et al., 1992). According to graphically presented results, there is no statistically significant difference in the xanthan concentration in media when reference strain, PFNS PL 3 strain, PFNS PL 4 strain or PFNS PL 5 strain are used.

The results of the statistical analysis of the effect of carbon sources on xanthan concentration in cultivation media at the end of biosynthesis are shown in Figure 1b. Graphically presented results indicate that the highest yields were achieved by cultivation of all examined Xanthomonas strains on the starch containing medium. The obtained results also show that there was no statistically significant difference in biopolymer concentration in media prepared with starch and glucose which is in accordance with the literature data indicating that the mentioned components are the most suitable carbon sources for the xanthan biosynthesis (Leela and Sharma, 2000).

The lowest concentration of xanthan in media was achieved using lactose as a carbon source (Figure 1b), in line with reported literature data (Leela and Sharma, 2000; Nikam et al., 2011). Lactose is a disaccharide consisting of $\beta$-D-galactose and $\beta$-D-glucose molecules that are bound by a $\beta-1,4$ glycosidic bond. Due to the low level of $\beta$-galactosidase present in Xanthomonas campestris the bacterium metabolize lactose in a lesser degree (Walsh et al., 1984). On the other hand, starch is a polymeric carbohydrate consisting of a large number of glucose units linked by $\alpha$ 1, 4 glycosidic bonds (Ogunsona et al., 2018). Considering the fact that Xanthomonas strains have the ability to synthetize amylolytic enzymes (de Crecy-Lagard, et al., 1990) responsible for hydrolysis of starch to glucose and that the most glucose (about $90 \%$ ) is primarily catabolized via the Entner-Doudoroff pathway in Xanthomonas campestris spieces (GarciaOchoa et al., 2004), it is clear why the results obtained by cultivation of different Xanthomonas strains on media with glucose and starch as carbon sources were at the same level of significance. From the results of Duncan's multiple range test presented in Table 4, it can be seen that 
the highest xanthan content was accomplished when the cultivation of PFNS PL4 was performed on starch containing medium $(13.20 \pm 0.76 \mathrm{~g} / \mathrm{L})$.

This result is in accordance with the literature data where similar xanthan concentration $(12.10 \mathrm{~g} / \mathrm{L})$ was obtained on medium with starch using Xanthomonas strain isolated from infected cabbage leaves (Leela and Sharma, 2000). It can also be noticed that there is no statistically significant difference between this results and the results of experiments where xanthan production were carried out by cultivation of the reference strain on glucose containing medium $(12.99 \pm 0.79 \mathrm{~g} / \mathrm{L})$ and cultivation of PFNS PL5 strain on starch containing medium $(12.55 \pm 0.78 \mathrm{~g} / \mathrm{L})$ which is confirmed by the $p$-values of 0.303566 and 0.154671 , respectively. It is important to note that the productivities of the examined strains on the glucose containing media obtained in this study are higher than those reported in literature data where xanthan content in the medium with higher concentration of glucose $(40 \mathrm{~g} / \mathrm{L})$ was from $6.40 \pm 0.55$ to $8.22 \pm 1.52$ $\mathrm{g} / \mathrm{L}$ (Gumus et al., 2010).

\section{Effect of producing strain and carbon source on xanthan quality}

The quality of xanthan depends on several factors, among which the producing strain, the cultivation medium composition and the process conditions are emphasized, and can be estimated based on several parameters, such as the composition of the macromolecules, the molecular weight, the viscosity of its solutions, etc. (Tait et al., 1986). Within this research, the quality of the produced biopolymer was estimated based on the apparent viscosity of its aqueous solutions. In order to determine the effect of different carbon sources and Xanthomonas strains on values of this parameter, a statistical analysis of the experimental data was performed. The results of Two-Way ANOVA analysis are given in Table 5 . The results presented in Table 5 suggest that the $p$-values for the analyzed parameters and their interaction are much lower than 0.05 , which indicate that the applied Xanthomonas strains and carbon sources as well as their combination have a statistically significant effect on the apparent viscosity of xanthan solution.

\section{Table 4}

Duncan's multiple range test: mean \pm standard deviation for xanthan concentration in media with various carbon sources obtained by cultivation of different Xanthomonas strains

\begin{tabular}{ccc}
\hline Xanthomonas strain & Carbon source & Xanthan (g/L) \\
\hline PFNS PL1 & Lactose & $2.24 \pm 0.32^{\mathrm{a}}$ \\
PFNS PL4 & Lactose & $3.32 \pm 0.27^{\mathrm{b}}$ \\
PFNS PL2 & Lactose & $3.35 \pm 0.37^{\mathrm{b}}$ \\
PFNS PL3 & Lactose & $3.46 \pm 0.33^{\mathrm{b}}$ \\
ATCC 13951 & Lactose & $4.40 \pm 0.43^{\mathrm{c}}$ \\
ATCC 13951 & Starch & $4.86 \pm 0.42^{\mathrm{c}}$ \\
PFNS PL2 & Glucose & $6.43 \pm 0.41^{\mathrm{d}}$ \\
PFNS PL1 & Glucose & $6.82 \pm 0.59^{\mathrm{d}}$ \\
PFNS PL4 & Glucose & $7.05 \pm 0.43^{\mathrm{d}}$ \\
PFNS PL5 & Glucose & $7.19 \pm 0.43^{\mathrm{d}}$ \\
PFNS PL2 & Starch & $7.32 \pm 0.43^{\mathrm{d}}$ \\
PFNS PL1 & Starch & $7.37 \pm 0.50^{\mathrm{d}}$ \\
PFNS PL3 & Starch & $8.73 \pm 0.51^{\mathrm{e}}$ \\
PFNS PL5 & Lactose & $9.03 \pm 0.64^{\mathrm{e}}$ \\
PFNS PL3 & Glucose & $9.57 \pm 0.56^{\mathrm{e}}$ \\
PFNS PL5 & Starch & $12.55 \pm 0.78^{\mathrm{f}}$ \\
ATCC 13951 & Glucose & $12.99 \pm 0.79^{\mathrm{f}}$ \\
PFNS PL4 & Starch & $13.20 \pm 0.76^{\mathrm{f}}$ \\
\hline
\end{tabular}

$\overline{a, b, \ldots}$ Values in the same column marked with the same letter are not significantly different at $\alpha=0.05$ 
Table 5.

Analysis of variance (Two-Way ANOVA) of the effect of different Xanthomonas strains and carbon sources on apparent viscosity of xanthan solution

\begin{tabular}{lrrrrc} 
Variability & \multicolumn{1}{c}{ SS } & \multicolumn{1}{c}{ DF } & \multicolumn{1}{c}{ MS } & F-value & $\boldsymbol{p}$-value \\
\hline Xanthomonas strains & 174.822 & 5 & 34.964 & 187.03 & $<0.000001$ \\
Carbon sources & 364.256 & 2 & 182.128 & 974.22 & $<0.000001$ \\
Xanthomonas strains and carbon sources & 62.467 & 10 & 6.247 & 33.41 & $<0.000001$ \\
Error & 6.730 & 36 & 0.187 & & \\
\hline
\end{tabular}

SS - sum of squares; DF - degrees of freedom; MS - mean square

a)

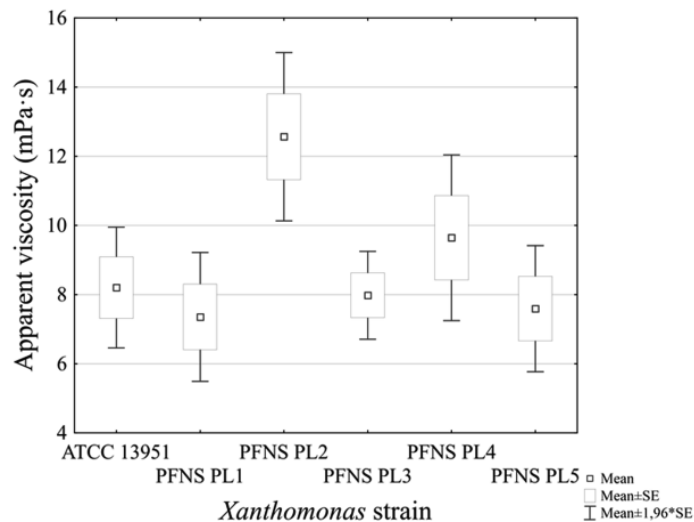

b)

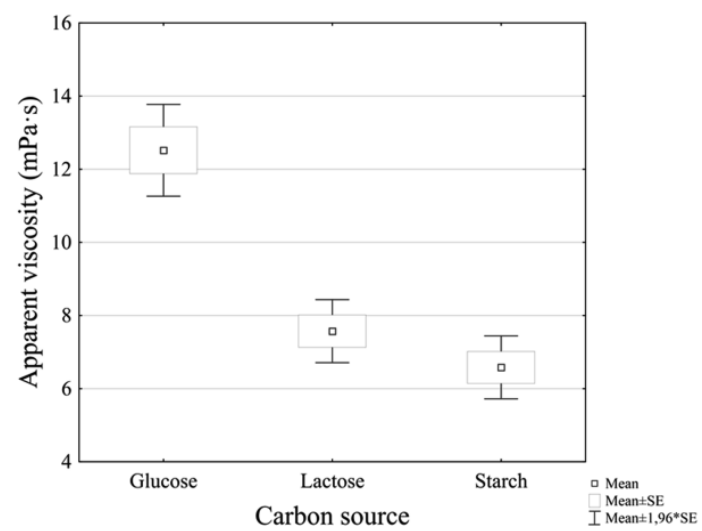

Figure 2. Effect of different Xanthomonas strains (a) and carbon sources (b) on apparent viscosity of xanthan solution

The mean square values presented in the same table show that the carbon source has a much greater effect on this group of results, while the effect of Xanthomonas strain is considerably lower. The results of the statistical analysis are also presented graphically in Figures $2 a-b$ and the experimental data was analyzed using Duncan's multiple range test whose results are presented in Table 6.

The results shown in Figure $2 \mathrm{a}$ represent statistical analysis of the effect of Xanthomonas strains on apparent viscosity of xanthan solution. Considering the mean value of this parameter for all carbon sources, the strain PFNS PL2 proved to be the best strain for good-quality xanthan production. The experiments carried out by cultivation of mentioned Xanthomonas strain on medium with glucose resulted in biosynthesis of xanthan which solution had the highest values of apparent viscosity $(17.51 \pm 0.57 \mathrm{mPa} \cdot \mathrm{s})$. On the other hand, cultivations of PFNS PL2 strain on lactose and starch containing media was less successful as the apparent viscosity of xanthan solutions was significantly lower (Table 6). According to graphically presented results (Figure 2a), it can be noticed that the PFNS PL4 strain also produced good-quality xanthan. The obtained results are in accordance with findings of Gumus et al. (2010) about the dependency of the used Xanthomonas strains and the viscosities of produced xanthan solutions.

Statistical analysis of the effect of carbon sources on apparent viscosity of xanthan solution is shown in Figure $2 \mathrm{~b}$. Graphically presented results indicate that xanthan solutions had the highest values of apparent viscosity when produced in a glucose containing medium, regardless of the Xanthomonas strain used as a producing microorganism.

This is in accordance with the results given in Table 6 , as well as with literature data indicating that xanthan of the highest quality can be biosynthesized on media with glucose as a carbon source (Rosalam and England, 2006). It can also be noticed that there was no statistically significant difference in the values of the analyzed parameter if lactose and starch are used as carbon sources for biopolymer production. 
Table 6.

Duncan's multiple range test: mean \pm standard deviation for apparent viscosity of xanthan solution produced by different Xanthomonas strains on media with various carbon sources

\begin{tabular}{ccc}
\hline Xanthomonas strain & Carbon source & Apparent viscosity (mPa·s) \\
\hline PFNS PL5 & Starch & $4.73 \pm 0.27^{\mathrm{a}}$ \\
PFNS PL1 & Lactose & $5.13 \pm 0.58^{\mathrm{ab}}$ \\
PFNS PL3 & Starch & $5.47 \pm 0.23^{\mathrm{abc}}$ \\
ATCC 13951 & Lactose & $5.69 \pm 0.54^{\mathrm{bc}}$ \\
PFNS PL1 & Starch & $5.83 \pm 0.34^{\mathrm{bc}}$ \\
PFNS PL4 & Starch & $5.94 \pm 0.39^{\mathrm{c}}$ \\
PFNS PL5 & Lactose & $7.00 \pm 0.41^{\mathrm{d}}$ \\
ATCC 13951 & Starch & $7.34 \pm 0.38^{\mathrm{d}}$ \\
PFNS PL4 & Lactose & $8.77 \pm 0.46^{\mathrm{e}}$ \\
PFNS PL3 & Lactose & $8.83 \pm 0.55^{\mathrm{e}}$ \\
PFNS PL3 & Glucose & $9.64 \pm 0.33^{\mathrm{f}}$ \\
PFNS PL2 & Lactose & $10.01 \pm 0.34^{\mathrm{f}}$ \\
PFNS PL2 & Starch & $10.18 \pm 0.37^{\mathrm{f}}$ \\
PFNS PL5 & Glucose & $11.06 \pm 0.31^{\mathrm{g}}$ \\
PFNS PL1 & Glucose & $11.10 \pm 0.32^{\mathrm{g}}$ \\
ATCC 13951 & Glucose & $11.58 \pm 0.68^{\mathrm{g}}$ \\
PFNS PL4 & Glucose & $14.23 \pm 0.42^{\mathrm{h}}$ \\
PFNS PL2 & Glucose & $17.51 \pm 0.57^{\mathrm{i}}$ \\
\hline
\end{tabular}

$\overline{a, b, \ldots}$ Values in the same column marked with the same letter are not significantly different at $\alpha=0.05$

The data presented in Table 6 are the results of the Duncan's multiple range test. These results suggest that the xanthan solutions with the highest values of apparent viscosity $(17.51 \pm 0.57 \mathrm{mPa} \cdot \mathrm{s})$ occured when the cultivation of PFNS PL2 strain was performed on the glucose containing medium. In addition, results of post hoc testing indicated that there was a statistically significant difference between the quality of xanthan obtained under the mentioned conditions and that obtained in other conditions, for example from xanthan produced on the starch containing medium by PFNS PL5 strain $(p=0.000017)$.

\section{CONCLUSIONS}

In this research the success of xanthan production using the reference strain Xanthomonas campestris ATCC 13951 and 5 Xanthomonas strains isolated from pepper leaves (PFNS PL1, PFNS PL2, PFNS PL3, PFNS PL4, PFNS PL5) on semi-synthetic media with various carbon sources (glucose, lactose and starch) was examined. The experimental data showed that both, the selection of the carbon source and selection of Xanthomonas campestris strain had a statistically significant effect on the xanthan quantity and quality. According to the results of statistical analysis, glucose and starch were the best carbon sources for accumulation of xanthan in media, whereas only glucose favors the biosynthesis of high quality xanthan. Taking into account other results, it can be concluded that Xanthomonas strains responsible for the production of a large amount of xanthan are not suitable for biosynthesis of good-quality biopolymer. However, the greatest potential for application in biotechnological production of xanthan was demonstrated by the strain PFNS PL4. The results obtained in this research may be a suitable background for future investigations.

\section{ACKNOWLEDGEMENTS}

This study is a result of the research conducted within the Project TR-31002, funded by the Ministry of Education, Science and Technological Development of the Republic of Serbia.

\section{REFERENCES}

1. Abedinzadeh, S., Torbati, M., Azadmard-Damirchi, S. (2016). Some qualitative and rheological 
properties of virgin olive oil-apple vinegar salad dressing stabilized with xanthan gum. Advanced Pharmaceutical Bulletin, 6 (4), 597-606.

2. Bajić, B., Dodić, J., Rončević, Z., Grahovac, J., Dodić, S., Vučurović, D., Tadijan, I. (2014). Biosynthesis of xanthan gum on wastewater from confectionary industry. Analecta, 8 (2), 13-17.

3. Bajić, B., Rončević, Z., Puškaš, V., Miljić, U., Dodić, S., Grahovac, J., Dodić, J. (2015). White wine production effluents used for biotechnological production of xanthan. Journal on Processing and Energy in Agriculture, 19 (1), 52-55.

4. Becker, A., Katzen, F., Pühler, A., lelpi, L. (1998). Xanthan gum biosynthesis and application: a biochemical /genetic perspective. Applied Microbiology and Biotechnology, 50, 145-152.

5. Björn, A., Karlsson, A., Svensson, B.H., Ejlertsson, J., de La Monja, P.S. (2012). Rheological characterization. INTECH Open Access Publisher.

6. de Mônaco Lopes, B., Lessa, V.L., Silva, B.M., da Silva Carvalho Filho, M.A., Schnitzler E., Lacerda, L.G. (2015). Xanthan gum: properties, production conditions, quality and economic perspective. Journal of Food and Nutrition Research, 54 (7), 185-194.

7. de Crecy-Lagard, V., Glaser, P., Lejeune, P., Sismeiro, O., Barber, C.E., Daniels, M.J., Danchinl, A. (1990). A Xanthomonas campestris pv. Campestris protein similar to catabolite activation factor is involved in regulation of phytopathogenicity. Journal of Bacteriology, 172 (10), 5877-5883.

8. García-Ochoa, F., Santos, V.E., Casas, J.A., Gómez, E. (2000). Xanthan gum: production, recovery, and properties. Biotechnology Advances, 18, 549-579.

9. García-Ochoa, F., Santos, V.E., Alcon, A. (2004). Chemical structured kinetic model for xanthan production. Enzyme and Microbial Technology, 35, 284-292.

10. Grahovac, M., Ignjatov, M., Aćimović, M., Budakov, D., Stojšin, V., Bagi, F., Tanović, B. (2016): Antibakterijska aktivnost etarskih ulja na Xanthomonas euvesicatoria. XV simpozijum o zaštiti bilja, Zlatibor, Serbia, Zbornik rezimea radova, $\mathrm{p}$. 93.

11. Green, M., Shelef, G., Bilanovic, D. (1994). The effect of various citrus waste fractions on xanthan fermentation. The Chemical Engineering Journal, 56, B37-B41.

12. Gumus, T., Demirci, A.S., Mirik, M., Arici, M., Aysan, Y. (2010). Xanthan gum production of Xanthomonas spp. isolated from different plants. Food Science and Biotechnology, 19 (1), 201-206.

13. Infee Sherley, K., Priyadharshini, R.D. (2015). Review on production of Xanthan gum in batch and continuous reactors. International Journal of ChemTech Research, 8 (2), 711-717.

14. Kumara, S.M., Khan, B.A., Rohit, K.C., Purushotham, B. (2012). Effect of carbon and nitrogen sources on the production of xanthan gum from Xanthomonas campestris isolated from soil. Archives of Applied Science Research, 4 (6), 25072512.

15. Leela, J.K., Sharma, G. (2000). Studies on xanthan production from Xanthomonas campestris. Bioprocess Engineering, 23, 687-689.
16. Nikam, A., Mundada, P., Chavan, A., Gonjari, G. (2011). Studies on acclimatization of xanthomonas campestris on whey for production of xanthan gum. The Bioscan, 6 (1), 43-45.

17. Niknezhad, S.V., Asadollahi, M.A., Zamani, A. Biria, D. (2016). Production of xanthan gum by free and immobilized cells of Xanthomonas campestris and Xanthomonas pelargonii. International Journal of Biological Macromolecules, 82, 751-756.

18. Ogunsona, E., Ojogbo, E., Mekonnen, T. (2018). Advanced material applications of starch and its derivatives. European Polymer Journal, 108, 570581.

19. Palaniraj, A., Jayaraman, V. (2011). Production, recovery and applications of xanthan gum by Xanthomonas campestris. Journal of Food Engineering, 106, 1-12.

20. Petri D.F.S. (2015). Xanthan gum: A versatile biopolymer for biomedical and technological applications. Journal of Applied Polymer Science, 132, 113.

21. Preichardt, L.D., Vendruscolo, C.T., Gularte M.A., da S. Moreira, A. (2011). The role of xanthan gum in the quality of gluten free cakes: improved bakery products for coeliac patients. International Journal of Food Science and Technology, 46, 25912597.

22. Rončević, Z., Vlajkov, V., Dodić, S., Grahovac, J., Dodić, J. (2018). Screening of Xanthomonas strains and standardization of inoculum preparation for xanthan production on winery wastewaters. $12^{\text {th }}$ symposium „Novel technologies and economic development", Leskovac, Serbia, Book of Abstracts, p. 53.

23. Rončević, Z., Zahović, I., Dodić, S., Grahovac, J., Dodić, J. (2017). Xanthan biosynthesis by Xanthomonas campestris ATCC 13951 on wastewaters from white grape processing. Ratarstvo $i$ povrtarstvo, 54 (3), 110-116.

24. Rosalam, S., England, R. (2006). Review of xanthan gum production from unmodified starches by Xanthomonas camprestris sp. Enzyme and Microbial Technology, 39, 197-207.

25. Roseiro, J.C., Esgalhado, M.E., Amaral Collaço, M. T., Emery, A. N. (1992). Medium development for xanthan production. Process Biochemistry, 27, 167-175.

26. Rottava, I., Batesini, G., Fernandes Silva, M., Lerin, L., de Oliveira, D., Ferreira Padilha, F., Toniazzo, G., Mossi, A., Cansian, R.L., Di Luccio, M., Treichel, H. (2009). Xanthan gum production and rheological behavior using different strains of Xanthomonas sp. Carbohydrate Polymers, 77 (1), 65-71.

27. Saha, D., Bhattacharya, S. (2010). Hydrocolloids as thickening and gelling agents in food: a critical review. Journal of Food Science and Technology, 47 (6), 587-597.

28. Selva Mohan, T., Babitha, R. (2010). Influence of nutritional factors on xanthan production by Xanthomonas malvacearum. Scholars Research Library, Archives of Applied Science Research, 2 (6), 28-36.

29. Sharma, B.R., Naresh, L., Dhuldhoya, N.C., Merchant, S.U., Merchant, U.C. (2006). Xanthan 
gum - A boon to food industry. Food Promotion Chronicle, 1 (5), 27-30.

30. Šuput D., Lazić V., Popović S., Hromiš N. (2015). Edible films and coatings - sources, properties and application. Food and Feed Research, 42 (1), 11-22.

31. Tait, M.I., Sutherland, I. W., Clarke-Sturman, A. J. (1986). Effect of growth conditions on the pro- duction, composition and viscosity of Xanthomonas campestris exopolysaccharide. Journal of General Microbiology, 132, 1483-1492.

32. Walsh, P.M., Haas, M.J., Somkuti, G.A. (1984). Genetic construction of lactose-utilizing Xanthomonas campestris. Applied and Environmental Microbiology, 47 (2), 253-257.

\title{
УТИЦАЈ ИЗВОРА УГЉЕНИКА НА ПРОИЗВОДЊУ КСАНТАНА СОЈЕВИМА ХАNTHОМОNАS SРР. ИЗОЛОВАНИХ СА ЛИСТОВА ПАПРИКЕ
}

\author{
Зорана 3. Рончевић ${ }^{1}$, Ида Е. Заховић¹ ${ }^{*}$ Ивана С. Пајчин ${ }^{1}$, Мила С. Граховац ${ }^{2}$, Синиша Н. \\ Додић ${ }^{1}$, Јована А. Граховац ${ }^{1}$, Јелена М. Додић ${ }^{1}$ \\ ${ }^{1}$ Универзитет у Новом Саду, Технолошки фракултет Нови Сад, 21000 Нови Сад, Булевар цара \\ Лазара бр. 1, Србија \\ ${ }^{2}$ Универзитет у Новом Саду, Пољопривредни фракултет, 21000 Нови Сад, Трг Доситеја \\ Обрадовића бр. 8, Србија
}

Сажетак: Ксантан је најважнији микробиолошки егзополисахарид који се примењује у различитим гранама прехрамбене и непрехрамбене индустрије. Због велике потрошње глукозе и сахарозе, најчешће коришћених извора угљеника у бројним биопроцесима, најактуелнија истраживања у прозводњи ксантана односе се на изолацију новог производног соја који може успешно да метаболише неке друге изворе угљеника и да при томе продукује ксантан са карактеристикама погодним за примену у прехрамбеној индустрији. Циљ овог истраживања био је да се испита утицај варијације извора угљеника у култивационим медијима за производњу ксантана применом референтног соја Xanthomonas campestris ATCC 13951 и пет Xanthomonas сојева изолованих са инфицираних листова паприке. Ефикасност биопроцеса процењена је на основу количине и квалитета биосинтетисаног ксантана. Добијени подаци показују да и избор извора угљеника и селекција производног соја имају статистички значајан утицај на ефикасност биопроцеса, при чему је утицај извора угљеника на вредност анализираних параметара израженији. Доказано је да Xanthomonas сојеви одговорни за производњу велике количине ксантана нису погодни за биосинтезу квалитетног биополимера. Узимајући у обзир све резултате, може се закључити да највећи потенцијал у биотехнолошкој производњи ксантана има coj PFNS PL4, као и медијум који садржи глукозу или скроб што представља основу за даља истраживања.

Кључне речи: биотехнолошка производња, ксантан, Хanthomonas campestris, cacmaв култивационог медијума, извор угљеника

Received: 25 February 2019

Received in revised form: 29 March 2019

Accepted: 11 April 2019 